\title{
Waqf Between the Past and Present
}

\section{Shadiya Mohamed S. Baqutayan ${ }^{1}$}

Aini Suzana Ariffin ${ }^{1}$

Magda Ismail A. Mohsin ${ }^{2}$

Akbariah Mohd Mahdzir ${ }^{1}$

${ }^{1}$ University Technology Malaysia (UTM)

${ }^{2}$ The Global University of Islamic Finance INCEIF

Doi: $10.2478 / m j s s-2018-0124$

\section{Abstract}

Waqf plays a very important role in Muslim societies. It has been the main source for various public services provided to communities. It has been marginalized as a mere charity, although it has historically been successful in producing sustainable income and reducing poverty levels in Muslim countries. Traditionally, the creation of Waqf is inculcated in Muslims' culture, and included all walks of life. It has also contributed to the service of man in various areas of development. Nonetheless, in modern times, Waqf has seen a declining role, which raises a number of questions as to what factors actually led to an earlier growth of Waqf, and what was the factor associated with its later decline. This review propagates a historical narrative of Waqf, highlighting the reasons for its decline and the need for reform. The paper concludes that if Muslims have good governments that can manage the funds are transparent, reformulates the laws governing Waqf, and design an integrated network of sciences to monitor issues and problems; they can realistically revive the practice of Waqf. The proper management and disbursement of Waqf can become a great source of revenue for the Ummah.

Keywords: Waqf, history of Waqf, Islamic civilization

\section{Introduction}

Waqf is a financial charitable act established by withholding immovable and movable properties to perpetually spend its revenue to fulfill public or family needs, based on the preferences and conditions set by the founder. Once the property is created as a Waqf, it can never be given as gift, inherited, or sold. It belongs to Allah (swt), and the Waqf property remains intact. Only its generated revenue is channeled to its beneficiaries (Magda, et al, 2016). The main motivation for a founder to create Waqf is clearly stated in both the Quran and the Sunnah. As highlighted in the Holy Quran, Surah Al-i'-Imran (3:92), the creation of Waqf is a way for founders to attain righteousness:

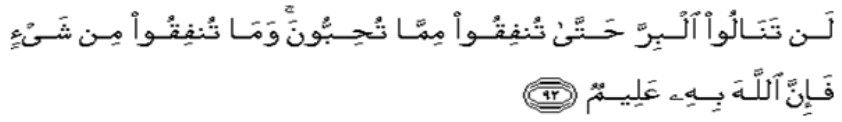

"Never will you attain the good [reward] until you spend [in the way of Allah] from that which you love, And whatever you spend - indeed, Allah is Knowing of it".

Islamic civilization has not only attained its progress due to the strength of its army, it is also 
due to the knowledge, good deeds and charitable endeavors of it people. What is known as the Waqf system is one of the characteristics that distinguished Islamic civilization from others. The Waqf contributed to the building of Islamic civilization; through which many mosques, schools, and educational centers were built along with private and public libraries, scientific and research centers and other fields in different walks of life. The Waqf is also an area for the competition of rulers, ministers, scientists, and individuals to establish laboratories for science, libraries, and collection of books from many countries at any price and making it available to everyone.

Waqf played an important role in establishing a flourishing civilization that is full of moral character and rational human behavior. It created a comprehensive scientific and cultural renaissance. Undeniably, Waqf funds contributed to the development of education and scientific movement in Islam. These funds were the main resource for schools, scientific centers, and libraries, which gave way to the training of many scientists, researchers, inventors, and intellectuals.

Indeed, Waqf is one of the factors for scientific and cultural prosperity in Islamic civilization. It is also one of the basic pillars for most public institutions. Unfortunately, the role of the Waqf disappeared from Muslim society, and today we are in dire need of this practice. In the past, many companions such as Othman, Talha, Zubayr, Ali, Ibn 'Umar, Abdullah Bin Amr Bin Al-Aas, and Khalid Bin Al Waleed created Waqf which further highlights its importance. This is what made Omar, may Allah be peace upon him, when the companions (Sahaabah) gave different opinion in dividing conquered lands, decided that the land should remain in the hand of its owners so that they can benefit from its wealth; but the control of the land and the land itself ought to be endowed as a Waqf for generations of Muslims perpetually (Lane, 2008).

The process of Waqf continued until the Ottoman era, when the Sultans and governors of the Ottoman state expanded the scope of Waqf, who introduce administrative formations for its supervision it, they issued multiple instructions to organize its affairs. However, the beginning of the $20^{\text {th }}$ century started the decline in the role of Waqf in Muslim life for many reasons, the most important of which was campaigns launched by opponents of the Waqf system. Waqf has been subjected to extensive campaigns of abolishment; unfortunately, the opponents of Waqf have succeeded in persuading the rulers to cancel Waqf and its control over many charitable endowments in many Muslim countries. The people are not in favor of traditional endeavors, which could be the reason that Muslims are in a state of decline. In order to understand Waqf and its roles in Islam, we will delve into the history of Waqf in the Islamic world, Waqf in building the Islamic civilization, the reasons for the decline of Waqf, and its need for reform.

\section{An Overview of the Study}

In Islamic history we can see great images and useful lessons about the status of Waqf and its impact on supporting the development of the Muslim community. Waqf was inculcated in Muslims' culture, is embedded in all walks of life, and has contributed to the service of the public in various areas of development. Waqf has also become a source of funding for Muslims over the centuries, due to large endowments (Awqaf) made by the prophet (Peace Be Upon Him) and his companions. Magda, et al, (2016) pointed out that Waqf covered almost all the needs of life during the early period of Islamic civilization; encompassing health, education, basic infrastructures, business and commercial activities, job creation, food provision for the hungry and livestock, shelter provision for the poor and needy, and supporting the agricultural and industrial sectors without any cost to the government. Imam Shafi' says: "more than eighty men of the companions participated in Waqf!" and Ibn Battuta said:" Endowments in Damascus were plentiful, uncounted, and unlimited."

However, current Waqf properties are that of idleness, neglect, and unproductiveness in almost all Muslim societies. Furthermore Waqf role decline significantly in Muslim society, according to Salman bin Mohammed Al Omari, (2017), "we need to change some of the negative culture that hits the Muslim community, and revive the concept Waqf again in our society". We look into the reasons for the decline of Waqf and ways to reform and reverse this decline. 


\section{Methodology}

The document analyzes literature on giving behavior, creating Waqf, and charitable activities. To realize our aim and objectives we include a comprehensive literature reviews encompassing information relevant to the study from previous publications, research papers, and other secondary data useful for this study.

\section{Literature Review}

The literature of this paper is divided into four parts:

\subsection{The History and creation of Waqf in Islam Among Muslim}

The ancient nations used to Waqif their properties and made it places of worship. The Waqf was not limited those days to places of worship; it was more than that, as one of the rulers of Nubia (Punut), during the reign of the fourth Ramesses, locked up his land and made a Willed, that the revenue of that land is to be used for buying a calf every year and scarified to his soul after his death. In the Roman era the government appointed a public servant to oversee the execution of the Waqf and in the Jaahiliyyah, the Arabs had houses of worship and temples where they stored what was offered as gifts then use it as a Waqf.

Waqf was created during the lifetime of the Prophet (Pbuh). Whenever the Prophet (Pbuh) identified any need in his society, he either fulfilled it by creating Waqf or encouraged his companions to fulfill it via the creation of Waqf. Thus, Muslims knew of Waqf, and idolized it during the lifetime of the Prophet (Pbuh), because the Prophet himself created many Waqf. The need for financial solidarity and social cooperation among Muslims emerged in the early age of Islamic history, due to many requirements and needs for the nascent Islamic state. The prophet and his companions worked very hard to find a source of money to fulfill these needs. Many verses of the Quran called upon the working and cooperation among Muslims and the in interdependence. The Messenger of Allah (Pbuh) said to his companions, " He who has land should cultivate it, but if he does not find it possible to cultivate it, or finds himself helpless to do so, he should lend it to his Muslim brother, but he should not accept rent from him." One of the greatest verses that encourages spending in the way of Allah is what Allah (swt) said in (2:261)

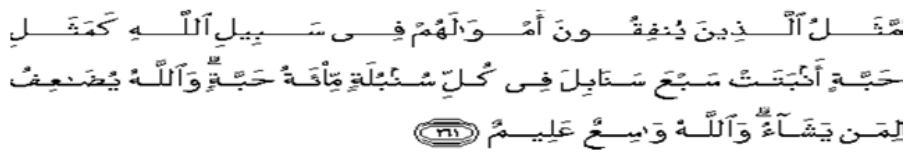

"Those who spend their wealth in the way of Allah and then do not follow up what they have spent with reminders [of it] or [other] injury will have their reward with their Lord, and there will be no fear concerning them, nor will they grieve."

The earlier Muslims hastened in giving the best they have, and choose the best charity for building mosques and other facilities. This is 'Umar (may Allah bless him) when he earned land in Khaybar, he came it to the Prophet (pbuh) and ask what to do with it, the Prophet (Pbuh) advised him to make it as a "Waqf": "If you wish, you should locked to its original and use the revenue for charity." Indeed, almost all companions of the prophet (pbuh) have created Waqf. According to AlKhasaf ((1322), from Muhammad Ibn Abd-Al-Rahman, from Sa'd ibn Zaraat: "All companions of the Messenger of Allah (Pbuh); from the people of Badr, immigrants (Muhajereen), and supporters (Ansaar), have made Waqf from what they earn, its neither be sale, nor be inherited, Until Allah inherits the earth and everything upon it. Indeed, the era of the Caliphs was the best Islamic era after the era of prophet, where the people took part into different charity. There were many Islamic Waqfs in various fields that have impacted Islamic civilization. 


\subsection{Waqf in Building Islamic Civilization}

Waqf is an important aspect of Islamic history, a great achievement of Ummah, a deep expression of thought and culture of Muslims, effective movements of Islamic societies, and a great expression of the nation. According to Saadallah, Abu al-Qasim, (1998), "Waqf is one of the most important aspects of Islamic civilization; it is a foundation that expresses the will of the Muslim and deep sense of solidarity with the Muslim community..." Indeed, the growth of Waqf in the Muslim world can be attributed to a number of factors; the strong religious believe and charitable desires of many Muslims is one of the factor that have led many people to make at least part of their property as a Waqf. Furthermore, Waqf has been used as a method to avoid taxation, Landowners made parts of their properties a Waqf to prevent other claimants from claiming the property (Hossein, 2013/Arabic source).

The viewer of Islamic civilization is surprised by the great effect Waqf had on the life of the Ummah, both in theory and practice. The Waqf of the Islamic community in the era of prophet Muhammad (pbuh) and his companion (Caliphate) fulfilled the needs of the society at that time, whether in terms of charity or the jihad requires for the sake of Allah. The purpose of creating Waqf varied from the $2^{\text {nd }}$ century $\mathrm{AH}$ to include social, scientific, and religious life. It began from the simple endowment for a family to what is known in the history of Waqf as a comprehensive end that benefits the Ummah.

The Waqf also played a major role in the scientific and cultural achievements of Islamic countries, (Hamish, 2008). These achievements are as follows;

- Dissemination of knowledge, building of schools, mosques, public libraries and Katateb to memorize the Holy Quran, and paying for the students' upkeep.

- Waqf of astronomical laboratories, science laboratories, and educational hospitals; to teach medicine, nursing, and pharmacology.

- The Waqf has also contributed to the preservation of the principles of Islam and the advancement of Islamic society, as well as spreading Islam.

- Prevent evangelized (the enemies) from the intellectually and destroying Islamic countries.

Waqf also helps organize human life, and elevates the status of the poor, strengthens the weak, employs the jobless, and preserves the life of the needy. It fulfills the expansion, progress, and development of Ummah, by supporting their meaningful projects and scientific researches.

\subsection{Reasons for the Decline of Waqf Creation}

A reader of Islamic history will easily discover that the Waqf represented important elements in the building of society and individual; it allowed financial realize access to public interests such as teaching students and paying for their studies upkeep, the establishment of hospitals or shelters, the allocation of funds for the construction of Mosque, or/and help the needy. However, recently the role of Waqf has declined, and wealthy Muslims begin not favoring charitable projects. According to Muhamed Umer Chapra (2008), that the Muslim world exhibited clear signs of decline by the $18^{\text {th }}$ century; after decades of advancement and prosperity. Indeed, according to Imam Aamar Jawdah (2016) at the end of the $19^{\text {th }}$ century, Muslims were plagued by intellectual, economic, and military invasions. The enemies during those days realized the importance of Waqf in assisting the Muslim communities; thus, they worked hard to eliminate the idea of Waqf and sequester its funds for their own end. They also tighten the laws in many Muslim countries by restricting the practice and supervision of the Waqf.

Mahdiya Amenouh (1426) indicated that the depletion of Waqf creation in the lives of Muslims is due to external and internal factors. The foremost is the negative influences left colonization of Muslim countries, especially the French, who transferred the Waqf offices from the Muslim governments to higher commissions, and hired non-Muslim advisers to work on their administrative and financial affairs. As a result, they have exhausted the Waqf coffers by paying salaries to those commission and officers. The British encouraged the immigration of Jews to the region to complete the cycle of control and colonial expansion. The power of authority was transferred from a colonial power to an occupying power. And as a result of this Waqfs were liquidated, and the administration 
and management of Waqf affairs went into decline.

Imam Aamar Jawdah (2016), narrated from Saad Al-Shathri stated three reasons for Waqf's decline: insufficient of some workers in Waqf institution, lack of trust, and lost of some Waqf properties as time passes due to the greediness of contain governors and sultans. Mahdiya Amenouh (1426) believed that the decline is due to internal challenges; the government or/and leaders who misused the Waqf in a manner contrary to the Shariah. They manipulated Waqf incomes, in a way that the individual lost the confidence and trust of these institutions. Similarly Hisham bin Azzah (2015), pointed out that Waqf creation in many Muslim countries decline due to reasons such as ambiguity about the size of Waqf and location, as well as government intervention in the acts of cessation and administration of Waqf. Furthermore, there are no establishments of new endowments (Waqf), and the majority of existing Waqf are from family inheritance.

According to Samia Al-Saati, (2010), the absence of Waqf has had the greatest impact on the social issuing such as poverty, unemployment, disease, insomnia and declining education. Money and property secured as a Waqf by the rich in the past were spent on the poor, provided jobs to the unemployed, educated the needy, treated the sick, and helped young men and women marry, but the lack of funds on Waqf in contemporary Muslim society lead to negative consequences. Here is an important question, why did the Muslims stop spending their money in favor of charitable projects?

It is stated in Waqafana (1427) by Ahmed al-Sharbasi; that "Waqf began to shrink due to several reasons; one of which is the control on people's action. Earlier, the life of a Muslim was generous; they were preparing for this life and hereafter. They were satisfying the demands of the legitimate self in life equally working hard to be near to God Almighty". Furthermore, Samia AlSaati, (2010) stated that "the scarcity of souls to become stingy, and the poor management of Waqf institution have led the people to leave practicing it". Thus, practicing Waqf has a significant impact on societal wellbeing, and the current situation might require us to revitalize it.

\subsection{The Need for Reform}

The Waqf has declined significantly in the present era. There is no longer a place for refuge in Muslim countries and work for the unemployed. In order for the Waqf to return to its past glow, the decision maker or/and leaders need to take some actions. According to Samia Al-Saati, (2010), Waqf should be organized in away that the governments themselves mange the funds. The governments administering Waqf led to the reluctance of Muslims to contribute to the Waqf, as they feel that it has been nationalized and used for other than that specified by the Waqf.

A key issue in Waqf is the need for transparency and assurance that the way assets and resources are managed, With transparency, stability, long-term planning and guidance, the prospects for Awqaf are great and the more we delay this, the more Waqf become vulnerable to progress (Hisham, 2013). It is therefore necessary to look into Waqf management policies, as well as investment of its assets. Efforts to renew the mechanisms of Waqf investment help to flourish, develop, return, and increase financing of the banks. The establishment of transparency of Waqf money is also very important. It will guarantee contributions and the success of endowment to civilize the nation and develop the country. According to Fouad bin Abdullah Al-Omar \& Basima bint Abdulaziz Al Maoud (2014), the application of inclusiveness governance rules via adoption of appropriate system, transparency, and disclosure of Waqf money to the main axes of Waqf foundation is; regarded as the best practices.

According to Reham Khafaji (2012), any efforts to revive the Waqf require reformulation of its laws. In addition to amending several other laws related to the establishment, management, investment, and the role of endowments, such as tax laws, civil society law, education, as well as health laws, the role of government in Waqf is essential. Additionally, Waqf revival requires an integrated network of sciences to monitor issues and problems, as well as propose development mechanisms linked to the establishment of several research centers and academic programs on Waqf studies. These centers must look into how to activate the culture of Waqf within the framework of an integrated civilizational vision based on its Waqf mission and interaction with economic, information, social and political transformations (Reham Khafaji, 2012). 
It is indicated by Imam Aamar Jawdah (2016) that the most important ways to face the challenge of Waqf declination is to spread religious awareness among the nation, awaken the religious feeling of solidarity, revival of jurisprudential councils, broadcasting the path of being good people, applying Shari'a in Waqf management, give the freedom to the Waqif to manage their respective Waqfs, pay more attention to the existing Waqf and develop it accordingly, establishing an effective economic plan that will take care of the Muslim Waqf, establishing specialized economic institutions that care of the Waqf, and finally the governors, scientists and leaders need to be excellent role models in the creation of Waqf.

Ultimately, the philosophy of the Waqf revolves around the formation of a good person who has been reformed in himself, his relationships, affiliations, and activities. Thus, its role is not limited to the provision of the necessary services to the individual, but also in establishing their respective affiliations, evaluating their relations, and rationalizing their interactions with others. In addition, Waqf offers a continuous model for further giving, by caring for the existence Waqf institutions, protecting Waqf funds and its members, investing its funds, distributing its profit according to the conditions of endowment and the needs of community, and finally promoting professional behavior and ethical values.

\section{Conclusion}

Waqf is a unique act introduced by Islam; it has played significant socioeconomic, cultural, and religious development roles throughout the history of Islamic civilization. In the past, the collection of large number of Awqaf created great wealth for the Muslim community; however, due to a different historical reasons the role of Waqf as a useful tool for socioeconomic development has generally been neglected or/and often been forgotten. Undeniably, as stated in this paper, researchers can see how Waqf contributed to the wellbeing of the people in various areas of development; such as education, health, and other services. Nonetheless, in modern times, Waqf role has declined significantly.

This paper describes the factor behind the decline of the Waqf, and our need to reform it. European colonization significantly influenced the structure of Waqf in Muslim majority countries, Muslims government or/and leaders who misused the Waqf properties, and the poor management of Waqf led to the decline of Waqf itself. Thus, Waqf revival requires governments who can manage the funds, funds transparency, reformulation of the laws governing Waqf, and an integrated network of sciences that monitoring issues and problems. The theoretical implication of this study is to understand Waqf. This study also provides practical contributions to Waqf research by identifying factors contributing to the decline of Waqf and ways to revive it. There are no empirical evidence on this, as this paper is only a conceptual paper. As part of ongoing research, the authors will continue to look into this matter. It is suggested that future research conduct a more comprehensive investigation on factors that led to Waqfs decline and ways to reform it.

\section{Acknowledgement}

I would like to express my special thanks of gratitude to The Ministry of Education as well as Universiti Teknologi Malaysia (UTM) who gave me the golden opportunity to do this wonderful project (Fundamental research grants), which also helped me in doing a lot of publications. I came to know about so many new things I am really thankful to them. My sincere thank also to all my colleagues who kindly provided valuable and helpful comments of this paper.

\section{References}

Al-Khasaf, A. A. A. (1322). Rulings of waqf. ( $1^{\text {st }}$ ed.). Egypt, Cairo: Library of religious culture.

Fouad A. A., \& Basima A. A. (2014). Waqf governance rules, Glasses of the endowment foundation model. [Online] Available: http://waqef.com.sa/upload/k96x1d7SSa12.pdf (November 20, 2017)

Hamish, A. (2008). Waqf and its impact on building Islamic civilization. UAE: Alshariqa University. 
Hisham, A. (2015), The role of Islamic instruments in the development and support of the Islamic Waqf sector. [Online] Available: http://giem.kantakji.com/article/details/ID/663\#.WXhhQoWp1v8 (November 10, 2017)

Hisham, D. (2013), Towards Effective Legal Regulations And Enabling Environment For Awqaf. [Online] Available: www.icrjournal.org/icr/index.php/icr/article/download/106/102/ (November 7, 2017)

Hossein, E. (2013), The Relationship Between The Waqf Institution In Islamic Law And The Rule Of Law In The Middle East. [Online] Available: http://waqfacademy.org/wp-content/uploads/2013/03/Dr-HosseinEsmaeili-HE.-Date.-Relationship-between-waqf-institution-in-islamic-law-rule-of-law.pdf (November 20, 2017)

Imam Aamar, J. (2016), Islamic endowments between past and present. [Online] Available: http://www.rabttaoulema-mr.com/?p=1211 (November 2, 2017)

Lane, D. (2008). International Documents on Israel \& Palestine 1915 to 2008. Singapore: Lulu Press, Inc.

Magda I. A., Hisham D., Murat C., Syed Othman A., Shaikh Hamzah A., Seyed Kazem S., Thamina A., \& Mohammed O. (2016). Financing The Development Of Old Waqf Properties; Classical Principles And Innovative Practices Around The World. New York: Palgrave Macmillan; Springer Science Business Media.

Mahdiya, A. (1426). The modern Islamic waqf: between the challenges of reality and the need for reform. Journal of the World, 186, 1-26.

Muhamed, U. C. (2008), Muslim civilization: The causes of decline and the need for reform. [Online] Available: https://www.researchgate.net/publication/265489395_Muslim_civilization_The_causes_of_decline_and_th e_need_for_reform (November 2, 2017)

Reham, K. (2012), Recommendations to revive the role of waqf in public policies and civil society. [Online] Available: http://www.moheet.com/2012/08/11/1650433 (November 10, 2017)

Saadallah, A. (1998). Algeria's Cultural History. ( $1^{\text {st }}$ ed.). Beirut: Dar al-Gharb al-Islami.

Samia, A. (2010), Waqf departed from Muslims community and applied in Westerners society. [Online] Available: http://www.alkhaleej.ae/supplements/page/24bfc720-15b7-41fd-b7d2-b3141b1bfe1d (November 20, 2017)

Waqafana (1427), Departure from the Waqf: Causes and Treatments. [Online] Available: http://www.waqfuna.com/v2/index.php?option=com_content\&view=article\&id=240 (November 13, 2017) 